\title{
Study of Development Trends and Development of Measures to Overcome Depopulation of Strategically Important Regions of Kazakhstan
}

\author{
Kalamkas I. Ibragimova ${ }^{1}$, Aisha B. Turysbekova ${ }^{1 *}$ \\ ${ }^{1}$ Institute of Economics CS MES RK, 28 Shevchenko Str., A25K1B0, 050000, Almaty, Kazakhstan
}

\begin{abstract}
This article deals with one of the most pressing issues today: the study of trends in the development and disappearance of the regions of Kazakhstan. The article discusses the features and opportunities of strategic development of regions in the Republic of Kazakhstan, as well as regional development trends and issues of regional extinction. The main relevance of the article is that it provides accurate information about trends in the development and disappearance of the regions of Kazakhstan. The purpose of the article is to consider possible ways to overcome negative trends in the country and improve depopulation and demographics. Scientific significance, Regional Development, and extinction issues, as well as comparative information on depopulation in the country, are presented. The practical significance of the work lies in the fact that the results of this work when studying demographics, become valuable information for students of higher educational institutions. The following research methods were used in the work: text analysis in the form of analysis of scientific literature affecting the study of demographics, comparative analysis in the form of study and generalization of information obtained during the study; as well as statistical methods, synthesis were used. As auxiliary methods of empirical research: comparison, generalization is used. The main conclusions and value of the study: the article presents the emergence of the problem of depopulation and the main reasons for the disappearance and depopulation of the regions of Kazakhstan. At the same time, the current state of development trends in Kazakhstan and current and new data on extinction and depopulation are provided.
\end{abstract}

Keywords: trends, regions, strategy, depopulation, Kazakhstan, disappearance, development.

For citation: Ibragimova, K.I., \& Turysbekova, A.B. (2021). Study of Development Trends and Development of Measures to Overcome Depopulation of Strategically Important Regions of Kazakhstan. Economics: the Strategy and Practice, 16(4), 76-89, https://doi.org/10.51176/1997-9967-2021-4 -76-89

* Corresponding author: Turysbekova A.B. - Master, researcher, Institute of Economics CS MES RK, 28 Shevchenko Str., A25K1B0, 050000, Almaty, Kazakhstan, e-mail: aisha9393@mail.ru

Conflict of interests: the authors declare that there is no conflict of interest.

Financial support: Исследование не имело спонсорской поддержки (собственные ресурсы).

The article received: 11.11 .2021

The article approved for publication: 13.12. 2021

Date of publication: 30.12 .2021 


\title{
Қазақстанның стратегиялық маңызды өңірлерінің депопуляциясын еңсеру бойынша даму трендтерін зерделеу және шаралар әзірлеу
}

\author{
Ибрагимова К.И. ${ }^{1}$, Турысбекова А.Б. ${ }^{1 *}$ \\ ${ }^{1}$ ҚР БҒМ ҒК Экономика институты, Шевченко 28, А25K1В0, Алматы қ., Қазақ̧стан
}

\begin{abstract}
Түйін
Бұл мақалада қазіргі күнгі ең өзекті мәселелердің бірі: Қазақстан өңірлерінің даму және жоғалу трендтерін зерттеу қарастырылады. Мақалада Қазақстан Республикасындағы өңірлердің стратегиялық даму ерекшеліктері мен мүмкіндіктері, сондай-ақ аймақтық даму тенденциялары мен аймақтардың жойылып кету мәселелері қарастырылады. Мақаланың басты өзектілігі: Қазақстан өңірлерінің даму және жоғалу үрдістері туралы нақты ақпарат береді. Мақаланың мақсаты ретінде, елдегі теріс үрдістерді еңсерудің және депопуляцияны, демографияны жақсартудың мүмкін жолдарын қарастыру болып саналады. Ғылыми маңыздылы, өңірлік даму және жойылу мәселелері және де елдегі депопуляция туралы салыстырмалы ақпарат ұсынылған. Жұмыстың практикалық маңыздылығы-бұл жұмыстың нәтижелерін, демографияны зерттеу барысында жоғары оқу орындары студенттентеріне құнды мәлімет болатынында. Жұмыста келесі зерттеу әдістері қолданылды: демографияны зерттеуге әсер ететін ғылыми әдебиеттерді талдау түрінде мәтінді талдау, зерттеу барысында алынған ақпаратты зерттеу және жалпылау түрінде салыстырмалы талдау; сонымен қатар статистикалық әдістер, синтез қолданылды. Эмпирикалық зерттеудің көмекші әдістері ретінде: салыстыру, жалпылау қолданылады. Зерттеудің негізгі тұжырымдары мен құндылығы: мақалада депопуляция проблемасының туындауы мен Қазақстан өңірлерінің жойылып кетуінің және депопуляциясының негізгі себептері көрсетілген. Сонымен қатар, Қазақстандағы даму трендтерінің ағымдағы жай-күйі және жойылып кету, депопуляция туралы өзекті және жаңа деректер берілгені саналады.
\end{abstract}

Түйін сөздер:үрдістер, аймақтар, стратегия, депопуляция, Қазақстан, жойылу, даму.

Дәйексөз алу үшін: Ибрагимова К.И., Турысбекова А.Б. (2021). Қазақстанның стратегиялық маңызды өңірлерінің депопуляциясын еңсеру бойынша даму трендтерін зерделеу және шаралар әзірлеу. Экономика: стратегия және практика, 16(4), 76-89, https://doi.org/10.51176/1997-9967-2021-4 -76-89

* Хат-хабаршы авторы: Турысбекова А.Б. - э.ғ.к., жетекші ғылыми қызметкер, ҚР БҒМ ҒК Экономика институты, Шевченко 28, А25K1B0, Алматы қ., Қазақстан, е-mail: aisha9393@mail.ru

Мүдделер қақтығысы: авторлар мүдделер қақтығысының жоқтығын мәлімдейді.

Қаржыландыру. Зерттеу демеушілік қолдау көрсеткен жоқ (меншікті ресурстар).

Мақала редакцияға түсті: 11.11 .2021

Жариялау туралы шешім қабылданды: 13.12.2021

Жарияланды: 30.12.2021 


\title{
Изучение трендов развития и разработка мер по преодолению депопуляции стратегически важных регионов Казахстана
}

\author{
Ибрагимова К.И. ${ }^{1}$, Турысбекова А.Б. ${ }^{1 *}$ \\ ${ }^{1}$ Институт экономики КН МОН РК, ул. Шевченко 28, А25K1В0, Алматы, Казахстан
}

\begin{abstract}
Аннотация
В данной статье рассматривается один из самых актуальных на сегодняшний день вопросов: изучение трендов развития и исчезновения регионов Казахстана. В статье рассматриваются особенности и возможности стратегического развития регионов в Республике Казахстан, а также тенденции регионального развития и проблемы исчезновения регионов. Главная актуальность статьи: дает реальную информацию о тенденциях развития и исчезновения регионов Казахстана. Целью статьи является рассмотрение возможных путей преодоления негативных тенденций в стране и улучшения депопуляции, демографии. Представлена сравнительная информация о научной значимости, проблемах регионального развития и деструкции, а также о депопуляции в стране. Практическая значимость работы заключается в том, что в процессе изучения результатов работы, демографии студенты высших учебных заведений получают ценные сведения. В работе использовались следующие методы исследования: анализ текста в виде анализа научной литературы, влияющей на изучение демографии, сравнительный анализ в виде изучения и обобщения информации, полученной в ходе исследования; а также использовались статистические методы, синтез. В качестве вспомогательных методов эмпирического исследования используются: сравнение, обобщение. Основные выводы и ценность исследования: в статье изложены основные причины возникновения проблемы депопуляции и исчезновения регионов Казахстана и депопуляции. Вместе с тем, в Казахстане представлены актуальные и новые данные о текущем состоянии и исчезновении трендов развития, депопуляции.
\end{abstract}

Ключевые слова: тренды, регионы, стратегия, депопуляция, Казахстан, исчезновение, развитие.

Для цитирования: Ибрагимова К.И., Турысбекова А.Б. (2021). Изучение трендов развития и разработка мер по преодолению депопуляции стратегически важных регионов Казахстана. Экономика: стратегия и практика, 16(4), 76-89, https://doi.org/10.51176/1997-9967-2021-4-76-89

* Корреспондирующий автор: Турысбекова А.Б. - магистр, научный сотрудник, Институт экономики КН МОН РК, ул. Шевченко 28, A25K1В0 г. Алматы, Казахстан, e-mail: aisha9393@mail.ru

Конфликт интересов: авторы заявляют об отсутствии конфликта интересов.

Финансирование. Исследование не имело спонсорской поддержки (собственные ресурсы).

Статья поступила в редакцию: 11.11 .2021

Принято решение о публикации: 13.12 .2021

Опубликовано: 30.12 .2021 


\section{Kipicne}

Қазіргі уақытта, әлемнің түрлі елдері, бір-бірінен географиялық жағдайы, климаты, демографиясы, даму тарихы мен басқа да факторлары бойынша ерекшеленеді. Бұл көптеген маңызды әлеуметтік-экономикалық мәселелерді тудырады. Бұл өз кезегінде аймақтардың даму тенденцияларына немесе жойылуына, сондай-ақ депопуляцияға әкеледі. Сондықтан әрбір мемлекет артта қалған өңірлерде өмір сүру деңгейін арттыруға, яғни бәсекелестік жағдайларды теңестіруге және өзінің даму деңгейін арттыруға бағытталған өңірлік саясатты жүргізуге ұмтылады.

Нарық жағдайында өңірлер инвестициялық ресурстар, салық төлеушілерді тарту, сондай-ақ ресурстардың барлық көздері мен өткізу нарықтары үшін бір-бірімен бәсекелеседі. Сонымен бірге, аймақтар ұлттық және халықаралық нарықтардағы тәуелсіз субъектілер болып табылады. Осы ретте У. Баймұратов, К.Қажымұрат, О. Сәбден, К. Сағадиев, Н. Нұрланова сияқты қазақстандық ғалымдардың осы тақырыптағы теориялық тәсілдерді зерделеу жөніндегі жұмыстары құнды болып саналады. Олардың зерттеулері бәсекеге қабілеттілік факторларынан, шарттары мен өлшемдерінен бастап өңірлер мен тұтастай елдің бәсекеге қабілеттілігін арттыру тетіктеріне дейінгі көптеген аспектілерге қатысты болды. Өңірлік экономиканың мәнін, негізгі қағидаттары мен даму факторларын ескеретін отандық және шетелдік ғалымдардың әдіснамалық және практикалық іргелі зерттеулеріне қарамастан, елдің және Қазақстан Республикасы өңірлерінің бәсекеге қабілеттілік деңгейін статистикалық бағалауды интеграциялауға байланысты көптеген мәселелер бар, елдің стратегиялық өңірлерінің депопуляциясын еңсеру бойынша тиімді шаралар әзірлеу, өңір үшін жаңа бәсекелестік мүмкіндіктерді іздестіру және игеру, оның ішінде отандық экономика жағдайында адами капиталдың сапасын арттыру есебінен саналады, дегенмен бұл ақпараттар әліде аз зерттелген [1, б.5-13].

Қазіргі Қазақстан өңірлік экономикалар ашықтығының жоғары дәрежесімен сипатталады; әлемдік экономикалық жүйеге кіретін ел өңірлерінің өзара байланысы мен өзара тәуелділігі беталысы барған сайын айқын бола түсуде. Сыртқы және ішкі ортаның, инфляция мен экономикалық өсудің күрт өзгеруіне байланысты экономикалық дағдарыс кезеңінде Қазақстан Республикасының әрбір өңірінің әлеуметтік-экономикалық дамуы республикалық және өңірлік деңгейлерде жоспарлау жүйесін пайдалануды талап етеді.
Оның мақсаты - республиканың, өңірлердің, жекелеген тұлғалардың және бизнесшаруашылық жүргізуші субъектілер нарығына қатысушылардың ұлттық экономикасының жұмыс істеуі мен дамуын ағымдағы, ұзақ мерзімді және стратегиялық жоспарлауды тұжырымдау болып саналады [2, б.94-97].

Әрбір өңірдің әлеуметтік-экономикалық дамуы, республиканың халық шаруашылығы, ресурстардың барлық түрлерін пайдалану тиімділігін арттыру ағымдағы жұмыс істеу негіздемесін жоспарлауға және есептеуге, перспективалы дамуға және өңірдің экономикасын нәтижелерге қол жеткізу үшін қажетті нәтижелерге сәйкес келтіруге, экономикалық өсу қарқынының ұлғаюын ғана емес айқындайтын әлеуметтік-экономикалық бағдарламаларды іске асыруға байланысты. Бұдан басқа, ұлттық және өңірлік экономиканың күйзеліске ұшыраған күйден шығуы, сондай-ақ әлеуметтік және материалдық игіліктерді тұтынудың өсуі, халықтың жұмыспен қамтылуының өсуі. Бұдан басқа, Қазақстандағы экономикалық өсу негізінен шикізат секторының озыңқы дамуымен байланысты. Егер өңірлерде шикізаттық тұрақтандыру және тіпті біршама өсу байқалса, онда бұрын білікті кадрлары бар және халықтың тығыздығы жоғары дамыған өңірлер үшін өндірістің құлдырауы тән, бұл олардың нарықтық қатынастарға көшуін қиындатады. Нәтижесінде Қазақстан өңірлерінің әлеуметтік-экономикалық саралануы мен депопуляциясы күшейе түсуде, оны еңсеру қиындай түсуде. Бұл мән-жайлар елдің әрбір өңірі үшін нақты даму стратегиясын айқындау және бірыңғай экономикалық кеңістіктің тиімді дамуын қамтамасыз ету мақсатында өңірлік факторларды тиімді пайдалануға жаңа тәсілдерді әзірлеуді және енгізуді және Қазақстанның өңіраралық қатынастарын зерделеуді талап етеді. Сондықтан бұл жұмыста Қазақстан өңірлерінің даму және жойылу трендтерінің ағымдағы жағдайы ғана талданбайды, сондай-ақ елдің стратегиялық маңызды өңірлерінің депопуляциясын еңсеру жөніндегі шараларды әзірлеу туралы тақырып көтеріледі [3, б. 36-46].

\section{Әдеби шолу}

Қазіргі уақытта өңірлік параметрлері дамыған жергілікті экономика мен жергілікті өзін-өзі басқаруды құруға мүмкіндік беретін елдерге қарағанда Қазақстан өңірлері үлкен аумақтармен, халық тығыздығының төмендігімен, өндірістік әлеуеттің жоғары шоғырлануымен және ұлттық экономиканың әлсіз әлеуетімен сипатталады. Қазақстан 
Республикасының аумағы 14 облыс, 3 Республикалық маңызы бар қала, 177 аудан, 89 қала, 50 ауыл және 6693 ауылдық елді мекеннен тұрады. Қала тұрғындарының саны 18,9 млн адамды құрайды. Елдің аумақтық және экономикалық даму ерекшеліктеріне сүйене отырып, аумақ әлеуетінің біркелкі дамымауы байқалады.Тарихқа үңіле отырып, Қазақстан Кеңес Одағының бір бөлігі бола отырып, Бірыңғай экономикалық жүйеде дамыды, барлық өндіргіш күштер Бүкілодақтық схема бойынша жүзеге асырылды деп айтуға болады. Бұл ретте Қазақстан өңірлерінің дамуы аз ескерілді. Қазақстан Республикасының Тұңғыш Президенті Н.Ә. Назарбаев өз Жолдауларында ел халқына Өңірлік даму реформасынсыз мәжбүрлеп әртараптандыруға қол жеткізу мүмкін еместігін және елді индустрияландыру өңірлік саясаттың жаңа парадигмасына айналуы тиіс екенін атап өтті [4, б. 82-96].

Аймақтың дамуы-бұл әр түрлі әлеуметтік-экономикалық міндеттер тұрғысынан қарастырылатын көп өлшемді және көп өлшемді процесс. Бұл тек экономикалық даму туралы болса да, ол әдетте әлеуметтік дамумен байланысты. Әлеуметтік-экономикалық даму келесі аспектілерді қамтиды:

- $\quad$ өндіріс пен кірісті ұлғайту;

- қоғамның институционалдық, Әлеуметтік және әкімшілік құрылымдарындағы өзгерістер;

- әлеуметтік хабардарлықтағы өзгерістер;

геруі.

- $\quad$ дәстүрлерменәдет-ғұрыптардыңөз-

Республиканың әр аймағында нарықтық қатынастардың қалыптасуы экономикада да, әлеуметтік салада да терең дағдарыстық құбылыстардың аясында өтті. Дегенмен, 20 жылдан астам уақыт ішінде Тәуелсіз Қазақстан жоспарлы-әкімшілік парадигмадан өңірлік дамудың жаңа демократиялық-нарықтық парадигмасына көшудің күрделі жолынан өте алды. Өндірістің даму деңгейі мен халықтың әлеуметтік тұрмыс деңгейі тұрғысынан Қазақстанның өңірлік кереғарлығы айтарлықтай жарқын. Арасындағы айырмашылықтар астаналық аймақ, тез дамушы аймақтар батыс және ауыл шаруашылығы өңірлерінің оңтүстігі мен солтүстігінде, қалалық және ауылдық мекендер арасында әсіресе көрсетілген. Бұл мән-жайлар Қазақстан Республикасының Үкіметін экономика мен халықты теңгерімді орналастыруға қол жеткізу мақсатында Елді «аумақтық қайта ұйымдастыруға» шоғырлануға мәжбүр етеді.
Республиканың өңірлері қазіргі халықтың құрамы бойынша ғана емес, демографиялық сипаттамалары мен даму үрдістері бойынша да айтарлықтай ерекшеленеді. Республиканың кейбір өңірлері бала туудың жоғары деңгейімен сипатталады (Атырау, Маңғыстау, Қызылорда, Оңтүстік Қазақстан облыстары), алайда балалар өлімі республикалық деңгейден 2-3 есе жоғары; басқаларында-ауылдық жерлер деңгейінде халықтың депопуляция белгілері (Шығыс Қазақстан, Павлодар, Қарағанды, Қазақстанның солтүстік өңірлері). Халықтың көші-қонында да терең айырмашылықтар бар. Халық саны азайды, әсіресе солтүстік және орталық аймақтарда - Ақмола, Қостанай, Солтүстік Қазақстан, Павлодар, Қарағанды. Негізгі себеп - механикалық құлдырау халықтың республикадан тыс жерлерге кетуі саналады. Сонымен қатар, бұл аудандарда бірнеше жыл ішінде өлім-жітімнің жоғары және туудың төмен деңгейімен бірге халықтың табиғи өсуінің ең төмен қарқыны байқалды [5].

Халықтың ішкі өңірлік ауысуында ауылдық жерлерден қалаларға әлеуметтікмәжбүрлі көші-қон басым болады, бұл қалалардың еңбек нарықтарындағы шиеленісті және олардағы криминогендік жағдайды шиеленістіреді. Ресми түрде азамат мәртебесін алған иммигранттар ic жүзінде әлеуметтік, өндірістік және мәдени өмір саласына араласпайды. Жұмыссыздыққа, тұрғын үйдің жетіспеушілігіне, еңбек нарығындағы бәсекеге қабілеттіліктің төмендігіне және экологиялық құндылықтардың өсіп келе жатқан рөліне қарамастан, қалалар республиканың ауыл халқын тартуды жалғастыруда. Бұл қалаларда кәсіби, Әлеуметтік және мәдени дамудың мүмкіндіктері әр түрлі болатындығына байланысты. Қызметтердің көптеген түрлерін ұсыну, мысалы, жоғары білім беру жүйесі, мамандандырылған медициналық көмек, ажырамас мәдени қызмет, тек үлкен қалада мүмкін. Ауыл халқының көптеген әлеуметтік жеңілдіктер мен қызметтерге нақты қол жеткізуі қоныстандыру жүйесінің ерекшелігіне негізделген [6, б.39-48].

Аумақтық еңбек бөлінісі және өңір экономикасының құрылымы жалпы өңірлік өнімнің (ЖӨӨ) көлемі және оның жан басына шаққандағы өндірісі сияқты жалпылама көрсеткіштермен неғұрлым толық сипатталады. Республиканың облыстарын ЖӨӨ бойынша бөлу біркелкі емес. Батыс аймағының барлық дерлік аймақтарында жоғары ЖӨӨ құбылысы мұнай-газ өндіретін кәсіпорындардың шоғырлануымен түсіндіріледі. Сонымен бірге, осы аймақтың барлық 
аудандары кең әлеуметтік-экономикалық тұрғыдан қолайсыз. Күрделі табиғи-климаттық жағдайлар, өмір сүру құны жоғары, соңғы жылдары ауылдық жерлерде жұмыссыздық күрт өсті, аудан орталықтарына, шағын және үлкен қалалар мен астанаға, сондайақ республикадан тыс жерлерге халықтың қарқынды көші-қоны басталды. Оңтүстік аймақта инвестициялық климат жақсаруда, бұл инвестициялық орталықтар мен полюстердің пайда болуына жағдай жасайды. Бұл ретте еліміздің негізгі инвестициялық капиталы шоғырланған Қарағанды, Қостанай, Павлодар және Шығыс Қазақстан облыстарында инвестициялар көлемі төмендеді. Көптеген елдердің тәжірибесі мынаны үйретеді: инвестицияларды біркелкі емес бөлу саясаты, әсіресе бұрынғы өнеркәсіптік аймақтарға қатысты, экономиканың аумақтық құрылымының өзгеруіне және әлеуметтікэкономикалық даму деңгейіндегі аймақаралық теңгерімсіздікке әкелуі мүмкін. Бұл сонымен қатар бұл аймақтарды проблемалық және депрессиялық аймақтарға біртіндеп айналдыруға мүмкіндік береді [7].

Инвестициялардың салалық құрылымында көбінесе өнеркәсіпке, көлік және коммуникациялық инфрақұрылымды дамытуға, сондай-ақ ауыл шаруашылығына келеді. Осы тұрғыдан алғанда, аймақтардың өзіндік ерекшеліктері бар. Экономикалық өңірлер арасында өнеркәсіпке инвестициялардың ең көп үлесі Батыс Қазақстанға, көлік пен байланысқа - Шығыс және Солтүстік Қазақстанға, ауыл шаруашылығына - оңтүстік өңірлерге тиесілі. Өңірлік дамудағы неғұрлым елеулі сәйкессіздіктер экономикалық қызметі негізінен ауыл шаруашылығы секторы болып табылатын қалалық және ауылдық аудандар арасында байқалады. Ауылдық өңірлердің негізгі мәселелері жұмыссыздықтың жоғары деңгейі, тұрмыс деңгейінің төмендігі, инфрақұрылымның нашар дамуы, үлкен аумақтар, елді мекендердің өткізу нарықтарымен нашар байланысы, көптеген ауылдық аумақтардың шеткері орналасуы және олардың орталықтардан едәуір шалғайлығы, қатал табиғи-климаттық жағдайлар, су ресурстарының өткір жетіспеушілігі, Арал теңізінің, Балқаштың, Семей полигонының экологиялық проблемалары, мұнай-газ кен орындарын қарқынды игеру және әскери полигондардың техногендік әсері болып табылады [8].

\section{Методология}

Осы мақаланы жазу кезінде, Қазақстанның аймақтарының даму және жойылу трендтерін зерттеу мақсатында, тақырыпты ашудың белгілі бір экономикалық, әлеуметтікистеорлық ғылыми әдістері қолданылды. Мақалада зерттелетін объект оның құрамдас бөліктерінің жиынтығы ретінде емес, жүйелік тәсілді қолдану нәтижесінде жүйе, тұтас құрылым ретінде қарастырылады. Тақырыпты толық ашу үшін осы мақаланы зерттеу барысында нақты ғылыми әдістеме қолданылды.

Мақалада аймақтардың даму және жойылу трендтерін қарастыру үшін, жалпы ғылыми әдістер мен тәсілдер, сондай-ақ нақты әдістер қолданылады. Қазақстанның даму және жойылу трендтері мен стратегиялық маңызды аймақтардың депопуляциясын еңсеруді зерттеуде, нақты ғылыми көздеріне және де статистикалық деректеріне негізделген. Сонымен қатар, еліміздің аймақтарының даму және жойылу трендтерін зерттеуде әдіснамалық негізді әлеуметтік құбылыстар мен процестерді танудың жалпы ғылыми және арнайы әдістері, сондай-ақ салыстырмалы талдау, салыстырмалы функционалды, жүйелікқұрылымдық және басқа әдістер құрады.

Келесі ретте, жалпы ғылыми әдістер ретінде диалектикалық, сонымен қатар логикалық әдістер мен жүйелік тәсіл қолданылды. Диалектикалық әдіс ел аймақтарының даму және жойылу, депопуляция тенденцияларын жан-жақты толық зерттеу үшін қолданылады. Өз кезегінде, ғылыми зерттеудің диалектикалық әдісі осы мақалада талдау және синтез әдістерін қолдануға негізделген [9].

\section{Нәтижелер мен талқылау}

Қазақстан үлкен аумақты алып жатыр. Демек, республика аймақтарында өндірістік күштерді ұтымды орналастыру және олардың арасындағы ұйымдастырушылық-экономикалық байланыстарды жақсарту үшін халық шаруашылығын аумақтық ұйымдастыру мәселелері жатады. Аумақтық ұйымға табиғи жағдайлардың әртүрлілігі, табиғи ресурстардың болуы және олардың орналасуы, елдің геосаяси жағдайы қатты әсер етеді. Тарихи қалыптасқан өндірістік аппараттың болуы, оның құрылымы, сондай-ақ оның моральдық және физикалық жағдайы маңызды рөл атқарады. Олардың жыныстық-жастық құрылымы, біліктілігі мен тәжірибесі бар қызметкерлердің болуы, сондай-ақ республика мен оның өңірлерінің алдында қазір және болашақта тұрған әлеуметтік-экономикалық міндеттер маңызды болып табылады [10]. 


\section{REGIONAL ECONOMY AND TERRITORIAL DEVELOPMENT}

Қазақстанда жүзеге асырылып жатқан экономикалық реформа әрбір өңірде экономикалық бірліктер мен ірі кешендерді қалыптастыру үшін экономиканы аумақтық ұйымдастыруға жаңа іргелі талаптар қояды. Сондықтан республиканың әр аймағындағы экономикалық, ұйымдастырушылық және әлеуметтік факторлар мен құбылыстардың жиынтығын зерттеу қажет. Мұндай жағдайда егемен мемлекет ретінде Қазақстан үшін өңірлік экономиканың рөлі өсті. Әр аймақтың өзіндік табиғи ерекшеліктері, ұйымдастырушылық және құрылымдық ерекшеліктері бар, әрқайсысының аймақтың экономикалық профилін анықтайтын өзіндік экономикалық және әлеуметтік жағдайлары бар.Еңбек ресурстарына сұраныстың біркелкі болмауына байланысты елде ішкі көші-қонды тартудың бірнеше орталықтары қалыптасты, оларға халық солтүстік өңірлерден «өтеді». Осылайша, LS Aqparat ақпарат агенттігінің 2021 жылдың бірінші тоқсанындағы деректері бойынша ел ішінде саяхаттауға ең қажетті орын Алматы болды, оған осы жылдың алғашқы үш айында 16900-ге жуық адам барды. Осы кезеңде Нұр-сұлтанға 16400 адам көшіп келді. Ішкі көшіп-қонушыларды тарту бойынша көшбасшылар бестігіне Шымкент (12 600 адам), Алматы (9300 адам) және Түркістан (7800 адам) облыстары кірді. LS Aqparat деректері «еңбек ресурстарын дамыту орталығы» АҚ өткізетін тоқсан сайынғы демография мен еңбек нарығын талдаумен ішінара сәйкес келеді. Осы зерттеуге сәйкес, 2019 жылдың III тоқсанында Қазақстанда халықтың өсуі Нұр-сұлтан (+ 4,1\%), Алматы (+ 3,0\%), Маңғыстау облысы (+ 2,7\%), Шымкент $(+2,5 \%)$ және Атырауда болды. аймақ $(+1,7 \%)$. Пайыздық қатынаста халық саны Солтүстік Қазақстан облысында $(-0,7 \%)$, Шығыс Қазақстан облысында $(-0,4 \%)$, Қостанай облысында $(-0,3 \%)$, Ақмола облысында $(-0,2 \%)$ және Павлодар облысында $(-0,1 \%)$ азайды. Ол төмендегі 1 суретте көрсетілген

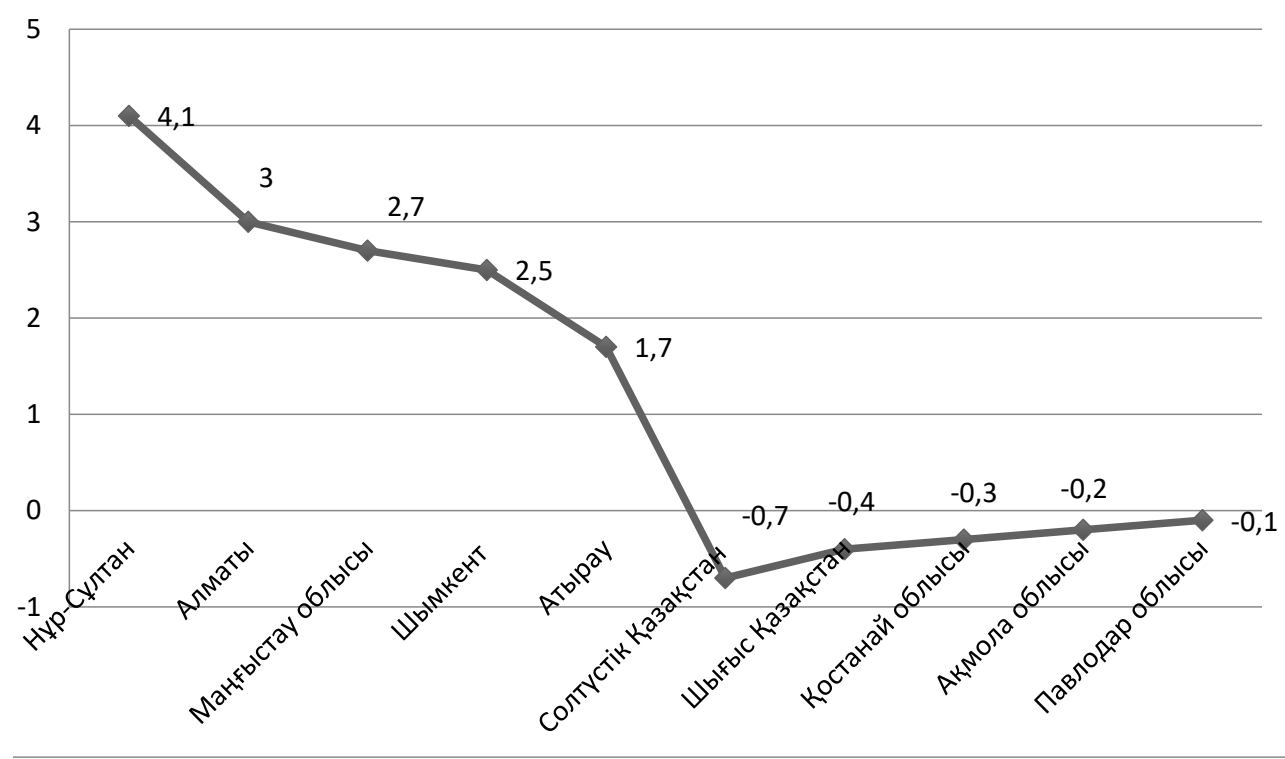

Сурет 1- Қазақстандағы халық санының өсуі

Figure 1- Population growth in Kazakhstan

2019 жылы сол кездегі Қазақстан Республикасының Еңбек және әлеуметтік қорғау министрі Біржан Нұрымбетов жасаған болжамдар бойынша 2050 жылы республика халқы артып, шамамен 24,5 миллион адамды құрайды. Бұл ретте Солтүстік Қазақстанда осы жылға қарай тағы 900 мың адамға азаюы мүмкін, ал оңтүстікте - 5,3 миллион адамға өсуі мүмкін [11].

Қазіргі уақытта республиканың солтүстігі мен оңтүстігі арасындағы қазіргі теңгерімсіздік келесідей (ағымдағы жылдың 1 сәуіріндегі жағдай бойынша): солтүстігінде 5450002 адам, Нұр-сұлтан қаласын қоса алғанда, оңтүстігінде 9169600 адам, Алматы мен Шымкентті ескере отырып. Оңтүстіктің пайдасына 3719598 адам. Қазіргі демографиялық теңгерімсіздікті азайту үшін Қазақстан Үкіметі өнімді жұмыспен қамтуды және жаппай кәсіпкерлікті дамытудың 2017-2021 жылдарға арналған «Еңбек» мемлекеттік бағдарламасын іске асыруда.Бұл бағдарламаның көші-кон құрамы серпиндік жобалардан және еңбек ресурстарының ұтқырлығын арттырудан 
тұрады. Екі вектор жұмыс күші артық аудандарды оның жетіспеушілігі бар аудандарға көшіруді ынталандыруға бағытталған. Тек «Серпін» ғана білім беру көші-қонына бағытталған, нәтижесінде жыл сайын Оңтүстік Қазақстаннан талапкерлер солтүстік, шығыс және батыс өңірлерінің университеттері мен колледждеріне жеке стипендиялармен түседі, содан кейін олар жатақханалар, стипендия және диплом алғаннан кейін жұмыс істейді. Еңбек ресурстарының ұтқырлығын арттыру жобасы аясында мемлекет оңтүстіктен солтүстікке көшуді шешкен ерікті мигранттарға қаржылық көмек көрсетеді.Бұл көмек пакетіне гранттар кіреді: көшуге; үйді жалға алу құнын өтеу және 12 айға ай сайынғы коммуналдық қызметтерді төлеу. Бұл жобаға ерікті Оңтүстік мигранттардан басқа, шетелдік қазақ диаспорасының өкілдері болып табылатын және Қазақстанға тұрақты тұруға көшуді шешкен этникалық қазақтар да қатыса алады. Қазақстан Республикасы Үкіметінің көші-қон процестерін Солтүстік пен оңтүстік арасындағы қазіргі демографиялық теңгерімсіздікті жоюға бағытталған әрекеттерінен басқа, бұл жобалар солтүстік өңірлердің этникалық ландшафтын өзгертуге ықпал етеді.

Пандемия Қазақстандағы көші-қон процестеріне әсер етті. 2020 жылы бір өңірден екінші өңірге қоныс аударатын қазақтардың саны 20\% - ға қысқарды. Одан да көп - 26\% - ға-өз өңірі шегінде тұрғылықты жерін ауыстыратын ауыл тұрғындары мен қала тұрғындарының саны азайды. Қазақстан Республикасы Стратегиялық жоспарлау және реформалар агенттігі Ұлттық статистика бюросының әдістемесіне сәйкес ішкі көші-қон өңіраралық және өңірлік болып бөлінеді. Бірінші бөлім бойынша ақпарат көрсеткендей, өткен жылы бір өңірден екінші өңірге 343 мың адам көшіп келген. 2019 жылы бұл көрсеткіш жоғары болды - 431 мың азамат. Ішкі көшіп-қонушылардың 86\% - ы-қазақтар. Басқа өңірлерден көшетіндердің жартысынан көбі (52\%) тұрақты тұруға ірі қалалар - Алматы (72,7 мың), Нұр-сұлтан (66,5 мың), Шымкент (39,4 мың) келеді. Осы мегаполистердің әрқайсысына мигранттар ағыны 2020 жылы 12-ден 22\% - ға дейін төмендеді. Ең үлкен кемшілік (22\%) елордада. Басқа аймақтарда көші-қон балансы теріс, яғни ұшуға қарағанда ұшу әлдеқайда көп. Көптеген өңірлерде көші-қон үрдістері ұқсас. Кеткендердің жартысы мегаполистерге, Ақмола, Алматы облыстарына, қалған 50\% көрші өңірлерге кетеді. Ішкі жер аударылған адамдардың ең үлкен ағымы оңтүстіктен келеді. 2020 жылы Түркістан, Жамбыл, Қызылорда, Алматы және Шымкент облыстарынан 167 мың азамат көшіп кетті [12].

Қазақстанда өңірлік көші-қон неғұрлым ауқымды. 2020 жылы 501,6 мың адам өз аймағына көшті. Бұл 178 мың азаматқа немесе 26 жылмен салыстырғанда 2019\% - ға аз. BNS статистикалық ақпараты әр облыстағы нақты қалалар мен ауылдарға бөлінбейді. Бірақ қалалық және ауылдық жерлерден көші-қон туралы жалпы мәліметтерге сүйене отырып, аймақ ішіндегі қозғалыс урбанизация сипатына ие деп айтуға болады. Адамдар ауылдардан қалаларға көшеді. Әлеуметтік жағдайы және өмір сүру деңгейі Қазақстан Республикасы Ұлттық экономика министрлігі Статистика комитетінің деректері бойынша 2018 жылдың басында Қазақстан халқының саны 18 миллион 157 мың адамға жетті. Ел тұрғындарының саны соңғы жылы 238,86 мың адамға артты, оның ішінде 260,49 мың адам табиғи өсім есебінен, 21,62 мың адам сол кезеңде Қазақстаннан кетті.Қазақстан Республикасы Президентінің жанындағы ҚСЗИ әлеуметтік-экономикалық зерттеулер бөлімінің аға ғылыми қызметкері Анна Альшанская халықтың өсу үрдісі ел бойынша күшейгенін және көші-қон процестеріне қарағанда халықтың табиғи өсуіне негізделгенін атап өтті. Алайда Қазақстан халқының өңірлік серпіні айқын саралануымен ерекшеленеді. Сарапшының айтуынша, ел аумағының басым бөлігіндегі халық жоғары табиғи өсім есебінен тұрақты өсуде. Сонымен қатар, ірі экономикалық орталықтарда - Астана және Алматы қалаларында, сондай - ақ батыс өңірлерде табиғи ағындар мен көші-қон ағындарының үйлесуі есебінен халықтың өсуі байқалады. Осылайша, Қазақстан Республикасының өңірлері арасында халықтың ең көп өсуі елордада байқалады - 59,78 мың адам. Өткен жылы Астанаға 35,53 мың адам келді, халықтың табиғи өсімі 24,45 мың адам-ды құрады. Еліміздің ең ірі қаласында Алматы халқы өсіп келеді, бір жыл ішінде ол 50,41 мың адамға, оның ішінде көші - қон есебінен 29,97 мың адамға ұлғайды.

Ел халқының ең күшті табиғи өсімін Қазақстанның оңтүстік өңірі көрсетіп отыр. Облыста бала туудың ең жоғары деңгейі - жылына 78,96 мың адам, алайда облыс статистикасы теріс таза көші-қонмен «көмескіленген». Нәтижесінде Қазақстанның оңтүстік өңірі халқының саны 2017 жылы 64,26 мың адамға артты. Сонымен қатар, солтүстік, шығыс және орталық өңірлердің халық саны қысқаруды жалғастыруда, өйткені теріс таза көші-қон, негізінен аймақаралық көші-қон оң табиғи өсіммен сәйкес келеді. 
Мәселен, Шығыс Қазақстан облысын, Солтүстік Қазақстан облысын, Қостанай, Қарағанды және Павлодар облыстарын қоса алғанда, Қазақстанның бес өңірінде халықтың кемуі байқалады. Қазақстанда 2017 жылдың төртінші тоқсанында орташа жалақы 163,73 мың теңге мөлшерінде белгіленді.

Ел өңірлерінің дамуымен қатар Қазақстан өңірлерінің жойылу проблемасы өткір тұр. Бүгінгі таңда республиканың әртүрлі аймақтарында табиғи ресурстарды ұтымды игеру маңызды міндет болып табылады, өйткені, біріншіден, өнеркәсіптік шикізат және отын базаларын орналастыру ел экономикасына тікелей әсер етеді; екіншіден, шикізат және отын ресурстарын өсіп келе жатқан тұтыну куатты шикізат және отын базаларының тармақталған желісін құруды талап етеді; үшіншіден, пайдалы қазбалар жақын болашақта экономиканы құрылымдық қайта құруды жүзеге асыру үшін қаражат жинақтауға мүмкіндік береді. Алайда, өздеріңіз білетіндей, біздің республикамыздағы табиғи ресурстар оның аумағында біркелкі бөлінбейді [13].

Нәтижесінде шикізат пен отын ресурстарын тұтынушыларға дейін тасымалдау қашықтығы артады. Демек, кеңістіктік (көлденең) өндірістік қатынастар өндіріс орталықтарының, көліктің, коммуникациялардың, шикізаттың, энергияның, дайын өнімнің және өнеркәсіптік және ауылшаруашылық өнімдерін тұтыну аймақтарының дұрыс үйлесімімен ғана оңтайлы бола алады. Қазақстан өңірлерін Стратегиялық жоспарлау қажеттілігін анықтау үшін өңірлерді негізгі көрсеткіштер бойынша талдаймыз. Қазақстан үшін демографиялық процестерге деген қызығушылық елдің халқы біркелкі бөлінбейтін халқы аз елдер санатына жататындығына байланысты. Қазақстан Республикасы аумағы бойынша әлемде 9 - шы орында, бірақ бұл ретте халықтың тығыздығы жоғары емесбір шаршы километрге шамамен 7 адамнан келеді.

Әлем халқының орташа тығыздығымен салыстырғанда (2018 жылғы деректер бойынша) шаршы километрге 55,7 адам, Қазақстандық көрсеткіш жеті еседен астам төмен. Бұл параметр бойынша ел әлемдік рейтингте тек 184-ші орында. Сондай-ақ республиканың солтүстік өңірлерінің жалғасып келе жатқан депопуляциясы теріс демографиялық фактор болып табылады. Бұл үрдіс КСРО ыдырағаннан кейін 1990-шы жылдардың басында, «орыс отандастары» ұғымына жататын орыстар мен басқа адамдар Қазақстаннан жаппай көшіқонды бастаған кезде қалыптаса бастады.
Түрлі бағалаулар бойынша Тәуелсіздік туралы Конституциялық заң қабылданған сәттен бастап алғашқы он жыл ішінде республикадан 1,5 миллионнан 2 миллионға дейін адам кеткен.

Негізінен аймақтардың жойылуы елдің солтүстігі мен шығысына қауіп төндіреді. Мысалы, Шығыс Қазақстанда сарапшылардың бағалауынша, алдағы жылдары 80-нен астам ауыл жойылып кетуі мүмкін. Тұрғындар жұмыс іздеп, жақсы жағдай іздеп қалалар мен ipi агломерацияларға барады. Катонқарағай ауданы бұл мәселеге қатты алаңдаулы. Біз бұл мәселені бірінші болып шешкіміз келеді. Ауданда арнайы инвестициялық форум өтті, онда халықтың көшіп кетуі тоқтатылды және нақты жобалар іске асыруға ұсынылды. Ал Солтүстік Қазақстан облысында 2021 жылғы 1 қаңтардағы жағдай бойынша 543679 адам тұрған. Өңір халқы негізінен тұрақты көші-қон есебінен қысқаруда. Коронавирус пандемиясына қарамастан, Солтүстік Қазақстан облысының халқы да осындай қарқынмен қысқаруда. Ұлттық статистика бюросының мәліметі бойынша 2020 жылы облыс тұрғындарының саны 5076 адамға, 548 755-тен 543679 адамға дейін азайды. 2019 жылмен салыстырғанда халықтың азаюы біршама төмендеді. Соңғы 10 жылда Солтүстік Қазақстан облысының халқы 45629 адамға азайды.

Жалпы, депопуляциямен күрес көбінесе мемлекеттің демографиялық саясатына байланысты. Қазақстанда депопуляция ауылдықтан қалалық өмір салтына ауысумен де байланысты. Осыған байланысты еліміздің басқа өңірлерінде өмір сүру деңгейін арттыру жөніндегі шаралар қажет. Бүгінгі таңда депопуляциямен күресудің бірнеше шаралары бар. Себебі олардың тиімділігі күмәнді. Демек, бізге жаңа шаралар әзірлеу қажет. Бүгінгі күні депопуляцияны еңсеру үшін келесі шаралар бар:

А) минимум-бағдарлама: 20 жастағы жастарға 3-4 баласы бар отбасын құруға көмектесу (тұрғын үй, әлеуметтік жәрдемақылар және т.б.).

Б) бағдарлама-максимум: отбасылық және демографиялық саясаттың мақсаттары өзара байланысты екі бөлікке бөлінген. Басқа әлеуметтік институттар арасындағы отбасының жағдайын өзгерту, қоғамдағы жаңа отбасын нығайту, халықтың азаюын жою жөніндегі стратегиялық міндет басты болып табылады. Оны жүзеге асыру 30-50 жылға созылады және сөзсіз екі-үш ұрпақты қамтиды. Орташа статистикалық балалардың (отбасындағы 3-4 бала) жаппай нормаларын 
қалыптастыру және нығайту мәселесі басқа әлеуметтік институттар арасындағы отбасы институтының қолайсыз жағдайын жою, отбасының дербестігін құқықтық қамтамасыз ету, мемлекеттік мекемелер мен отбасы арасындағы әлеуметтік келісім, жұмыс пен үйге деген адалдық негізінде отбасылық өндірісті нығайту үшін ұзақ күш салуды талап етеді. Тағы да, үй шаруасындағы аналардың класын зейнетақымен қамтамасыз етумен қайта құру, жалақы жүйесіне отбасылық жалақыны енгізу, жас отбасыларға жеңілдетілген салық салу мен несие енгізу және принцип аясында басқа да бірқатар шаралар жатады.

Тағы бір міндет «жөндеу түрі» - депопуляция мен отбасылық дағдарыстың қазірдің өзінде елеулі теріс салдарын бейтараптандырумен, жағымсыз құбылыстарды бәсеңдетуге, олардың әсерін негізгі мақсатты іске асыру нәтижелеріне дейін шектеуге тырысумен байланысты.ата-аналары мен бірнеше балалары бар отбасын нығайту саясаты. Демографиялық дамудың қолданыстағы тұжырымдамасы аясында иммиграциялық саясат пен денсаулықты жақсарту және өлімді азайту шараларымен бірге мақсаттары, кестесі мен құралдары тұрғысынан нақты балалары бар толық отбасыларды ынталандыру бағдарламаларын жасау қажеттілігі туындайды. Қазіргі уақытта елдің болашағын анықтайтын негізгі факторлар-туу және отбасы.Қазақстанға оның өмір сүруіне қауіп төндіретін депопуляциядан біржола айығу үшін демографиялық жұмылдыру қажет. Дәл осы отбасы мемлекет пен қоғам тарапынан ең үлкен экономикалық және моральдық қолдау алуы керек [14].

Жалпы алғанда, елдің стратегиялық маңызды аймақтарының депопуляциясын жеңу шаралары әдетте әртүрлі шаралар жиынтығы арқылы жүзеге асырылады. Бұл 1 кестеде көрсетілген.

Кесте 1 - Депопуляция жеңу шаралары

Table 1 - Measures to overcome depopulation

\begin{tabular}{|c|c|l|}
\hline № & \multicolumn{1}{|c|}{ Шаралар } & \multicolumn{1}{|c|}{ Сипаттамасы } \\
\hline 1 & экономикалық & $\begin{array}{l}\text { ақылы демалыстар және бала тууы бойынша жәрдемақылар; балаларға } \\
\text { олардың санына, жасына, отбасы түріне қарай жәрдемақылар; несиелер, } \\
\text { кредиттер, салықтық және тұрғын үй жәрдемақылары және т. б. }\end{array}$ \\
\hline 2 & әкімшілік-құқықтық & $\begin{array}{l}\text { неке, ажырасу, балалардың отбасындағы жағдайы, алименттік міндеттемелер, } \\
\text { ана мен баланы қорғау, түсік түсіру және контрацептивтерді пайдалану, } \\
\text { мүгедектерді әлеуметтік қамтамасыз ету, жұмыс істейтін әйел-аналардың } \\
\text { жұмыс жағдайлары мен жұмыс режимі, ішкі және сыртқы көші-қон және т. б. }\end{array}$ \\
\hline 3 & жалпы & $\begin{array}{l}\text { қоғамдық пікірді, демографиялық мінез-құлық нормалары мен стандарттарын, } \\
\text { қоғамдағы белгілі бір демографиялық ахуалды қалыптастыруға бағытталған } \\
\text { тәрбиелік және насихаттау іс-шаралары. }\end{array}$ \\
\hline
\end{tabular}

Ескерту: Автормен жасалынған

Сондай-ақ, сіз келесі бөлімдерді қамтитын бағдарламаны жасай аласыз:

1. дағдарысқа қарсы шаралардың басым бағыттары;

2. ұйымдастыру шешімдері және ақпараттық қолдау;

3. халықты әлеуметтік қорғауды күшейту, әлеуметтік және медициналық көмек көрсету, білім беру, мәдениет, дене шынықтыру және спорт;

4. еңбек нарығын тұрақтандыру;

5. экономиканың нақты секторындағы өндірістерді қолдау;

6. шағын және орта бизнесті дамытуға жәрдемдесу;

7. бюджетті басқару.

Қазақстандағы демографиялық ахуал жалпыұлттық проблема. Еңбек нарығында кадрлардың жетіспеушілігі тенденция ретін- де көптеген жылдар бойы дамып келе жатқан кезде, тұтыну нарықтарында демографиялық құлдырау белгілері енді ғана пайда бола бастады. Сарапшылар алдағы жылдары нарықтың барлық сегменттері жылжымайтын мүліктен Тұрмыстық техника мен электрониканың бөлшек саудасына дейін популяциялық «шұңқырға» ауыса бастайды деп болжайды. Тәуекел тобында динамикасы отбасылардың сандық және сапалық құрамымен тікелей байланысты салалар. Болашақ өзгерістердің қауіпті белгілерін жастар аудиториясына бағытталған компаниялардың сату құрылымындағы өзгерістерден көруге болады. Сарапшылардың пікірінше, мигранттар-бұл білімі төмен және біліктілігі төмен кадрлар. Кем дегенде қазіргі уақытта. Мүмкін, уақыт өте келе жаңадан келгендердің ынтасы Қазақстан экономикасын тезірек 
алға жылжытуға мәжбүр етуі мүмкін. Сурет Жоғары мектептегі жағдаймен күрделене түседі. Егер мемлекеттік университеттер әлсіз студенттерді «тартуға» тырысса, жаңа коммерциялық университеттер оқуға түсетін жастарға жеңіл курстар ұсына бастады. «Прогрессивистер» өз окушыларының тілінде сөйледі. Көптеген әлеуметтанушылардың бағалауы бойынша, 2001-2002 жж. «Коммерциялық» университеттердің клиенттері елдегі түлектердің жартысына жуығын құрайды.

Депопуляцияны жеңудің үлкен әлеуметтік-экономикалық маңызы бар. Өйткені, халықтың депопуляциясы халықтың айтарлықтай азаюына әкелді, бұл уақыт өте келе жұмысшылардың санына тікелей байланысты еңбек ресурстарының өсуіне әсер етеді. Осы ретте тағы бір маңызды аспект - ірі қалалар мен жекелеген аумақтардың көптігі. Сонымен қатар, этникалық мигранттардың қоныс аударуы халық тығыз орналасқан аймақтарда да жүреді. Айта кету қажет, бұл тұрғыда шекара маңы аумақтарының депопуляциясы және солтүстік аймақтарда, әсіресе еңбекке қабілетті жаста халықтың азаюы орын алады. Болашақта бұл осы өңірлерде экономикалық өсуді қамтамасыз етуде қиындықтарға алып келеді және тұтастай алғанда елдің ұлттық қауіпсіздігіне әсер етуі мүмкін.Мұның бәрінің себебі - экономикалық жағдай, табыс пен жұмыс деңгейі және басқа да жағдайлар. Ол арқылы адамдар еліміздің әртүрлі өңірлерінен республикалық маңызы бар қалаларға көшеді. Яғни, қалалардың даму үрдісі неғұрлым тез өссе, аймақтардың жойылу деңгейі де соғұрлым жоғары болады. Бұл проблемаларды шешу үшін біздің елімізге елдегі депопуляцияны еңсеру шаралары қажет. Бұл үшін бізге экономикалық дамуды, ішкі көшіп-қонушылар үшін лайықты жұмыс орындарын құруды, гендерлік теңдікті, көшіп-қонушылардың құқықтарын қорғауды қамтамасыз ететін барынша тиімді бағдарламалар жасау қажет, сондай-ақ еңбек көші-қоны, адам саудасы мәселелерін шешу әзірленетін тұжырымдама басымдықтарының бірі болуға тиіс. Сондай - ақ, адам капиталы тұрғысынан денсаулықбұл ұлттық байлықты қалыптастыруға тікелей қатысатын сала. Денсаулық сақтау жүйесі адамдардың денсаулығын қалпына келтіруге арналғандықтан, мемлекет үшін осы сала жұмысының экономикалық мәні елдің адами капиталын қалпына келтіру және көбейту болып табылады; толыққанды зияткерлік және еңбек дамуы үшін, сондайақ адами ресурстарды жаңарту көзі ретінде репродуктивтік функцияны іске асыру үшін жағдайлар жасау болып табылады. Осылайша,
Денсаулық сақтау жүйесі бүкіл экономикалық кешеннің жұмысына айтарлықтай үлес қосады және оның жұмысының тиімділігін экономикалық тұрғыдан бағалау керек [15].

\section{Қорытынды}

Қорытындылай келе, Тәуелсіз Қазақстан өңірлерін дамытудың жаңа жағдайларына байланысты «жаңа өңірлік саясатты» қалыптастыру және іске асыру жүріп жатыр, ол мынадай ерекшеліктермен сипатталады.

Біріншіден, мемлекеттік қайтарымсыз субсидиялардың орнына жергілікті деңгейде орталықтандырылмаған бастамаларды және өзін-өзі басқаруды қолдау. Мұндай саясаттың оң нәтижесі Италия мен Қытай сияқты елдерде болды.

Екіншіден, өсім ең кедей аймақтарда ынталандырылады және сақталады, бұл Бразилияның белсенді аймақтық саясатында көрінеді, бұл елдің салыстырмалы түрде кедей солтүстік-шығыс аймақтарына әсер етті.

Үшіншіден, өңір мен елдің бәсекелестік артықшылықтарын пайдалануды, сондайақ өңірлік «өсу нүктелерін» дамытуға жәрдемдесуді қамтамасыз ететін кешенді тәсіл қолданылады. Инновацияға және ғылыми-техникалық салаға, адами капиталға инвестицияларға көп көңіл бөлінеді.

Төртіншіден, қазіргі уақытта әлемдік экономиканың жаһандануы жағдайында дәстүрлі экономикалық көрсеткіштермен қатар ақпараттық, ұйымдастырушылық және географиялық жағдай сияқты жаңа элементтерді қамтитын өндіргіш күштердің құрамына кең көзқарас таралды.

Қазақстан Республикасының Еуразия құрлығының ортасындағы қолайлы географиялық орналасуы оған халықаралық көлік дәлізі болуға мүмкіндік береді, ал жеткілікті дамыған көлік инфрақұрылымы бар аумақтық артықшылықты пайдалану ел экономикасының тиімді көлік құрылымын қалыптастыруда елеулі рөл атқара алады. Өңірлік саясатты іске асырудың аталған тәсілдері өңірлердің экономикасын жаңғыртуға, экономикалық өсуге, әлеуметтік даму мен экологиялық қауіпсіздік үшін жағдай жасауға бағытталған. Дегенмен, бүгінде Қазақстанда депопуляцияның өсуі байқалады, ол негізінен елдің солтүстік өңірлерінде жүреді. Бұл жерде демографиялық статистика халық пен мемлекеттің көші-қон мүдделері сәйкес келмейтінін көрсетеді, «оңтүстік дрейф» Қазақстандағы негізгі көші-қон тренді болып қала береді. Солтүстіктен оңтүстікке өз еркімен көшетіндердің арасында Қазақстанның солтүстігіндегі демогра- 
фиялық «олқылықтарды» толтыруға тырысып жатқан ерікті қоныс аудару жобаларының қатысушылары болмайтыны факт емес [16].

Өткен жылы орын алған демографиялық проблемадан шығуды Қазақстан Президенті Қ.-Ж. Тоқаев ұсынды. Қазақстан халқына екінші Жолдауында ол көлемі шамамен 30 миллион адамды құрайтын Ресейдің шекара маңындағы нарығына назар аударуды ұсынды. Шынында да, Ресейдің шекаралас аймағында шоғырланған компаниялардың пайда болуы республиканың солтүстігінен ішкі және мүмкін сыртқы көші-қонды азайтуға жағдай жасай алады. Ресейдің әртүрлі аймақтарында шекара арқылы халықтың қоныс аударуының ұқсас процестері жүретіні белгілі, сондықтан экономикалық саладағы шекаралық ынтымақтастық екі ел шекарасының демографиясына жағымды әсер етуі мүмкін.

Алайда, республиканың солтүстігінде депопуляция проблемасын неғұрлым тиімді шешу - ата-бабалары елу жүз немесе екі жүз жыл бұрын осы аймақты қайта құруға келген, тарихи және тарихи тұрғыдан байырғы тұрғындары болған адамдар үшін қолайлы өмір сүру жағдайларын жасау. табиғи-климаттық тұрғыдан. Мәселен, мысалы, осы аймақтағы орыс тілін мемлекеттік тілмен қатар қолдануға болатын «аймақтық» тіл ретінде тану, сондай-ақ «үштілділік рельстеріне» өтпейақ орыс тілінде білім беретін мектептердің сақталуы осы жерден сыртқы көші-қонды тоқтатар еді. Басқаша айтқанда, әзірге айтарлықтай нәтижелер әкелмеген баламалы демографиялық саясаттың орнына этносаясатты өзгертуге болар еді, бұл бірқатар елдердегі, сондай-ақ Қазақстан Республикасының өңірлеріндегі демографиялық жағдайға оң әсер ететіні сөзсіз. Осылайша, еліміздің аймақтарының даму және жойылу трендттерін зерттеу және стратегиялық маңызды аймақтардың депопуляциясын еңсеру жөніндегі шараларды әзірлеу өте маңызды мәселе болып саналады.

Қорытындылай келе, біз бұл мақалада еліміздің аймақтарының даму және жойылу трендтеріне зерттеу жүргіздік. Сонымен қатар стратегиялық маңызды аймақтардың депопуляциясын анықтап, оларға арнайы шараларады қарастырдық. Жасалынған зерттеу жұмысы нәтижесінде, біз келесідей қорытындыға келдік: «Қазіргі уақытта Қазақстанның кейбір өңірлерінің дамуына және жойылуына алып келетін елдегі әртүрлі жағдайлар депопуляцияға алып келеді. Ө3 кезегінде, депопуляция жас және дамушы мемлекет үшін маңызды проблемалардың бірі болып табылады. сондықтан, бізге стра- тегиялық маңызды өңірлердің депопуляциясын еңсеру жөнінде белгілі бір шаралар әзірлеу аса қажет» [17, б.432-433].

\section{Әдебиеттер тізімі:}

1. Артемова О.В. Негізгі тренд- тер өңірлік даму: мүмкіндіктер дәлізі. О.В. Арте- мова, А. Н. Савченко. ЮУрГУ Хабаршысы// Серия Экономика және менеджмент. - 2019.- № 13 (3). - С. $5-13$.

2. Тұрмағанбетова А.Қ. Қазақ- стан Республикасындағы өңірлердің стратегиялық даму ерекшеліктері мен мүмкіндіктері, экономикалық ғылым және практика: IV халықаралық материалдар. ғылыми. конф. (Чита). - Чита: 2016, Жас ғалым баспасы, 94-97.

3. Афонцев С.А. Санкции и международные институты: перспективы снижения санкционных рисков для России// Вестник международных организаций. - 2019. - Т. 14(3). - С. $48-68$.

4. Nurlanova, N.K. (2014). Scenarios of innovative development of regions of Kazakhstan and assessment of opportunities for their implementation. Problems of territorial development, 4 (72), 82-96.

5. Мусабалина Д.С., Киреева А.А. Оценка уровня инновационного развития регионов Казахстана и возможности их дальнейшей кластеризации//Экономика: стратегия и практика. 2019. - № 14(1). - C. 149-161.

6. Nurlanova N.K., Satybaldin A.A., Bekturganova M.A., Kireyeva A.A. Spatial distribution of economic growth and inequality: Kazakhstan>s experience // Journal of Asian Finance, Economics and Business. - 2018. - № 5(3). - C. 169-178.

7. История создания, философия, векторы развития; 2021 [обновлено 21 июня 2021; процитировано 29 октября 2021]. Доступно: https:// ia-centr.ru/han-tengri/journal.

8. Темірова А.Б., Әбдімомынова А.Ш. (2016). Қазақстан өңірлерінің әлеуметтікэкономикалық саралануы. РУДН Хабаршысы, Экономика сериясы, 1, 58-69.

9. Ахметжанов Б.А., Тәжібекова К.Б., Хишауева Ж. Т. Қазақстан Республикасының Өңірлік дамуын стратегиялық жоспарлау// ҚарМУ хабаршысы. - 2016. - № 2(82). - С. 118-124.

10. Қазақстан Республикасының Президенті - Елбасы Н.Ә.Назарбаевтың «Қазақстан 2050» Стратегиясы: қалыптасқан мемлекеттің жаңа саяси бағыты» атты Қазақстан халқына Жолдауы. - [ЭР]. Қатынау режимі: www. online. zakon.kz

11. Бюро национальной статистики; 2021 [обновлено 19 октября 2021; процитировано 30 октября 2021]. Доступно: http://www.stat.gov.kz.

12. Курсив-Қазақстан бизнес Жаңалықтары; 2021 [2021 жылдың 24 қарашасында жаңартылды; 2021 жылдың 29 қарашасында келтірілген]. Қолжетімді: https://kursiv.kz/tag/kursivresearch. 


\section{REGIONAL ECONOMY AND TERRITORIAL DEVELOPMENT}

13. Қазақстан Республикасы Әділет министрлігі; 2018 [2019 жылдың 27 желтоқсанда жаңартылды; 2021 жылдың 10 қарашасында келтірілген]. Қолжетімді: https://adilet.zan.kz

14. Сарапшылар Қазақстанның солтүстік өңірлеріндегі халық санының азаюын атап өтті; 2021 [2021 жылдың 23 қарашасында жаңартылды; 2021 жылдың 30 қарашасында келтірілген]. Қолжетімді: http://inform.kz.

15. Депопуляция: дағдарыстық жағдайдан шығу жолдары. Ғалымдар әзірлеген бағдарлама; 2021 [2021 жылдың 12 қарашасында жаңартылды; 2021 жылдың 25 қарашасында келтірілген]. Қолжетімді: http://xn--80aa2bkafhg.xn--p1ai

16. Ресейлік БАҚ Қазақстанның солтүстігінен емес, тұрғындарынан айырылып қалу қаупі бар екенін айтады : бұл қанша шындықжаңалықтар | Керуен; 2021 [2021 жылдың 20 қарашасында жаңартылды; 2021 жылдың 29 қарашасында келтірілген]. Қолжетімді: https:// www.caravan.kz

17. Исагалиева А.С. Репродуктивті мінезқұлық халықтың депопуляциясы факторы ретінде. А. С. Исагалиева, Ю. г. Миронова// Мәтін: тікелей. Жас ғалым. - 2015. - № 2(82). - С. 432-433.

\section{References:}

1. Artemova, O.V. (2019). Main trends of regional development: a corridor of opportunities. O. V. Artemova, A. N. Savchenko. Bulletin of Yuurgu. Series Economics and management, 13 (3), 5-13. (In Russ.)

2. Turmaganbetova, A.K. (Chita, April 2016). Features and opportunities of strategic development of regions in the Republic of Kazakhstan. economic science and practice: IV International materials. scientific. Conf. - Chita: young scientist publishing house, 94-97. (In Russ.)

3. Afontsev, S.A. (2019) Sanctions and international institutions: Prospects for reducing sanctions risks for Russia. Bulletin of International Organizations, 14(3), 48-68. DOI: 10.17323/19967845-2019-03-03. (In Russ.)

4. Nurlanova, N.K. (2014). Scenarios of inno- vative development of regions of Kazakhstan and assessment of opportunities for their implementation. Problems of territorial development, 4 (72), 82-96. (In Russ.)

5. Mussabalina, D.S.., Kireyeva, A.A. (2019). Assessment of the level of innovative development of the regions of Kazakhstan and the possibility of their further clustering. Economics: the Strategy and Practice, 14(1), 149-161. (In Russ.)

6. Nurlanova, N.K., Satybaldin, A.A., Bekturganova, M.A., Kireyeva, A.A. (2018). Spatial distribution of economic growth and inequality: Kazakhstan >s experience. Journal of Asian Finance, Economics and Business, 5(3), 169-178. (In Russ.)

7. History of creation, philosophy, vectors of development; 2021 [updated June 21, 2021; cited October 29, 2021]. Available: https://ia-centr.ru/hantengri/journal. (In Russ.)
8. Temirova, A.B., Abdimomynova, A.Sh. (2016). Socio-economic differentiation of the regions of Kazakhstan. Bulletin of the RUDN, Economics Series, 1, 58-69 (In Russ.)

9. Akhmetzhanov, P.A., Tazhibekova, K.B., \& Hishaueva, Zh. T. (2016). Strategic planning of regional development of the Republic of Kazakhstan. Bulletin of Karsu, 2(82), 118-124. (In Russ.)

10. Address of the president of the Republic of Kazakhstan - Elbasy N. A. Nazarbayev to the people of Kazakhstan "strategy" Kazakhstan - 2050: a new political course of the established state". - [ER]. Access mode: www.online.zakon.kz. (In Russ.)

11. Bureau of National Statistics; 2021 [updated October 19, 2021; cited October 30, 2021]. Available: http://www.stat.gov.kz. (In Kaz.)

12. Italics-Kazakhstan Business News; 2021 [updated on November 24, 2021; cited on November 29, 2021]. Available: https://kursiv.kz/tag/kursiv-research. (In Kaz.)

13. Ministry of Justice of the Republic of Kazakhstan; 2018 [updated on December 27, 2019; cited on November 10, 2021]. Available: https://adilet. zan.kz. (In Kaz.)

14. Experts noted a decrease in the population of the northern regions of Kazakhstan; 2021 [updated on November 23, 2021; cited on November 30, 2021]. Available: http://inform.kz. (In Kaz.)

15. Depopulation: ways out of a crisis situation. A program developed by scientists. 2021 [updated on November 12, 2021; cited on November 29, 2021]. Available: http://xn--80aa2bkafhg.xn--p1ai. (In Russ.)

16. Russian media say that Kazakhstan is in danger of losing its inhabitants, not the north: how much is the truth-News | caravan; 2021 [updated on November 20, 2021; cited on November 29, 2021]. Available: https:// www.caravan.kz. (In Kaz.)

17. Isagalieva, A.S. (2015). Reproductive behavior as a factor of depopulation of the population- Text: direct. Young Scientist, 2 (82), 432-433. (In Russ.) 


\section{Information about the authors}

Kalamkas I. Ibragimova - Candidate of Economic Sciences, Leading Researcher, Institute of Economics CS MES RK, Kazakhstan, e-mail: ilayskalamkas@mail.ru

* Aisha B. Turysbekova - Master, researcher, Institute of Economics CS MES RK, 28 Shevchenko Str., A25K1B0,050000,Almaty, Kazakhstan, e-mail: aisha9393@mail.ru

\section{Авторлар туралы мәліметтер}

Ибрагимова К.И. - э.ғ.к., жетекші ғылыми қызметкер, ҚР БҒМ ҒК Экономика институты, Қазақстан,е-таil: ilayskalamkas@mail.ru

* Турысбекова А.Б. - магистр, ғылыми қызметкер, ҚР БҒМ ҒК Экономика институты, Қазақстан,е-таil: aisha9393@mail.ru

\section{Сведения об авторах}

Ибрагисова К.И. - старший научный сотрудник, Институт экономики КН МОН РК, Казахстан, е-таil: ilayskalamkas@mail.ru

* Турысбекова А.Б. - магистр, научный сотрудник, Институт экономики КН МОН РК, Казахстан, е-таil: aisha9393@mail.ru 